\title{
ARTIFICIAL NEURAL NETWORK APPROACH FOR THE PREDICTION OF EFFLUENTS STREAMS FROM A WASTEWATER TREATMENT PLANT: A CASE STUDY IN KOCAELI (TURKEY)
}

Esra BILGIN SIMSEK*, Department of Chemical and Process Engineering, Faculty of Engineering, Yalova University, Turkey, esrabilgin622@gmail.com, ebilgin.simsek@yalova.edu.tr

(iD) https://orcid.org/0000-0002-2207-3855)

Taner ALKAY, Department of Chemical and Process Engineering, Institute of Nature Sciences, Yalova University, Turkey, taneralkay@gmail.com

(iD) https://orcid.org/0000-0001-9712-2546)

Received: 11.09.2019, Accepted: 30.06.2020

*Corresponding author

Research Article DOI: $10.22531 /$ muglajsci.618373

\begin{abstract}
A three-layer Artificial Neural Network (ANN) model was employed to develop and estimate the effluent stream parameters of two different wastewater treatment plants (WWTP) in Kocaeli, Turkey. The chemical oxygen demand (COD), suspended solid (SS), pH and temperature as the output parameters were estimated by five input parameters such as flow rate, COD, $p H$, SS and temperature. The ANN model was developed with 400 data sets for prediction of effluent $p H$, temperature, COD and SS. The benchmark tests were employed to achieve an optimum network algorithm. The network model with optimum functions at hidden and output layers were applied for the forecasts of effluent streams of both WWTPs. The regression values of training, validation and test using this function were found as 0.94, 0.96 and 0.95, respectively. The optimum neuron numbers were determined according to the minimum mean square error values. ANN testing outputs revealed that the model exhibited well performance in forecasting the effluent $\mathrm{pH}$, temperature, SS and COD values.
\end{abstract}

Keywords: Artificial neural network, Back propagation, Prediction, Waste Water Treatment Process

\section{ATIKSU ARITMA TESIS ÇIKIŞ SUYUNUN YAPAY SINIIR AĞLARI İLE TAHMİNi: KOCAELİ (TÜRKIYY) İLİ ÖRNEK ÇALIŞMASI}

Özet

Bu çalışmada; Kocaeli (Türkiye) ilinde bulunan iki farklı atıksu arıtma tesis çıkış suyu parametreleri üç katmanlı Yapay Sinir Ağları (YSA) ile değerlendirilerek modelleme yapılmıștır. Çıktı parametreleri olarak belirlenen kimyasal oksijen ihtiyacı (KOİ), askıda katı madde (AKM), pH ve sıcaklık değerleri beş girdi parametresi (akış hızı, KOİ, AKM, pH ve sıcaklık) ile tahmin edilmiştir. YSA modeli 400 veri seti ile gelişstirilerek çıkış suyu $\mathrm{pH}$, sıcaklı, KOİ ve AKM değerlerinin modellemesi yapılmıştır. YSA eğitimi için optimum algoritmayı belirlemek amacıyla birçok kıyaslama testleri gerçekleștirilmiștir. YSA modeli; gizli katmanda tanjant sigmoid transfer fonksiyonu (tansig) ve çıkış katmanında lineer transfer fonksiyonu (purelin) optimum olarak belirlenmiştir. Bu fonksiyonları kullanarak eğitim, validasyon ve test setleri için regresyon değerleri sırasıyla 0.94, 0.96 ve 0.95 olarak bulunmuștur. Gizli katmanda optimum nöron sayısı minumum ortalama kare hata değeri temel alınarak saptanmıştır. Elde edilen sonuçlara göre YSA modelinin çıkış suyu pH, sıcaklık, KOİ ve AKM değerlerinin tahmininde etkin ve doğru performans gösterdiği belirlenmiştir.

Anahtar Kelimeler: Yapay Sinir Ağı, Geri Yayılım, Tahmin, Atıksu Arıtma Prosesi

Cite

Bilgin Simsek, E., Alkay, T. (2020). “Artificial neural network approach for the prediction of effluents streams from a wastewater treatment plant: a case study in Kocaeli (Turkey)”, Mugla Journal of Science and Technology, 164-171.

\section{Introduction}

Among the chemometric methods, mathematical modelling offers cheap and fast option for the conventional analytic solutions which are useful to analyze the process structure and the correlations between the components [1]. Among the mathematical tools, artificial intelligence models such as artificial neural network (ANN), neuro-fuzzy (NF) or, fuzzy logic (FL) can efficiently overcome nonlinear and complex systems by 
using numerical analysis [2], [3]. The ANN is a powerful tool involving the examination of a process by using network weights to obtain the desired response [4]. From an engineering point of view, ANN can be regarded as a heuristic model for predicting and classifying the data connecting from I/O data performance [5], and can be applied for modelling and controlling of nonlinear systems in processes [6], [7].

In the last decades, the application of artificial neural network has gained popularity in modelling wastewater treatment plants. In domestic and industrial usages, water quality is dependent on monitoring the key variable via obtaining the required impact of operation and ensuring the desired standards and protocols [8]-[12]. ANN predicts output data corresponding with inset data after a learning period [13]. In addition, ANN has capability of learning non-linear functions without necessity for the structural process input [14]. Holubar et al. [15] developed feed forward ANN algorithm to estimate the methane production. Cinar [16] have found that the application of Kohonen self-organizing feature maps (KSOFM) neural network was efficient on the evaluation of WWTP performance. Chen et al. [17] applied ANN model to obtain well estimation for nitrogen amount in effluent streams. Nasr et al. [18] predicted Chemical Oxygen Demand (COD), Biochemical Oxygen Demand (BOD) and Total Suspended Solids (TSSs) data of a WWTP by using ANN with Feed Forward Back-Propagation. Dias et al. [19] applied ANN with neural fuzzy model for controlling and modelling the outputs of WWTPs. Harrou et al. [9] developed a machine learning model to detect potential mistakes in WWTPs. Raduly et al. [20] found the accuracy of ANN is sufficient with correlation coefficients $\mathrm{R}^{2}>0.95$ and prediction errors lower than $10 \%$, in order to apply in simulated WWTP. Nadiri et al. [21] proposed three FL models for a WWTP using influent water quality data (BOD, COD, $\mathrm{pH}$, temperature, and TSSs). They have found that the trained ANN model provided a better estimation for the WWTP than the FL methods.

Although there are several ANN models for WWTPs have been proposed in literature, few studies were reported about the comparison of ANN modelling of WWTPs which have different influent properties. Therefore, the aim of this work was to investigate the ANN modeling to predict the effluent of two wastewater treatment plants in Kocaeli, Turkey. Kocaeli is one of the industrialized and urbanized cities in Turkey. The two WWTPs namely 'Kullar' and '42 Evler' have different influent characteristics and the municipality has planned to combine these two WWTPs in one facility. Therefore, this research investigated and compared the prediction of effluent $\mathrm{pH}$, temperature, COD and SS using feed forward ANN trained with the back propagation algorithm.

\section{Materials and Methods}

\subsection{Kullar and 42 Evler Wastewater Treatment Plants (WWTPs)}

The Kullar WWTP treated municipal and industrial wastewater with an average capacity of about 20,000 $\mathrm{m}^{3} /$ day in summer and $27,726 \mathrm{~m}^{3} /$ day in winter months. The difference in flow rate is due to the by-pass stream of wastewater from balancing tank in rainy days winter months. The Kullar WWTP was a biological plant including activated sludge process to remove organic carbon and nitrogen. Between 2012-2014 years, the average influent stream capacity was $20,712 \mathrm{~m}^{3} /$ day including $43 \%$ industrial and $57 \%$ municipal wastewater.

The 42 Evler WWTP was established at 1988 and treated $60 \%$ municipal and $40 \%$ industrial wastewater by using activated sludge process. The plant comprised fine and coarse screens, inlet pump station, sand filters and ventilated air treatment, a pretreatment unit, activated sludge aeration tanks, sludge thickener and sludge dewatering system. The 42 Evler WWTP receives the wastewater of about 47 industries.

\subsection{Wastewater Characteristics}

The analysis of the wastewater characteristics in the WWTPs was carried out daily. In the composite samples, the COD, BOD, TSS, total phosphorus (TP), total nitrogen (TN), mixed liquor volatile suspended solids (MLVSS), $\mathrm{pH}$, color and $\mathrm{T}\left({ }^{\circ} \mathrm{C}\right)$ are measured at the ISU Central Laboratories in Kocaeli. The COD, BOD, TSS, and MLVSS measurements were performed according to the standard methods. The TN and TP values were analyzed according to the methods of DIN EN ISO 11905-1 and TS EN ISO 11885, respectively. The $\mathrm{pH}$ and $\mathrm{T}^{\circ}\left({ }^{\circ} \mathrm{C}\right)$ are measured using electrometric method.

\subsection{ANN Modelling}

In this study, all data were separated into input matrix [p] and target matrix [t]. Five process variables like influent $\mathrm{pH}, \mathrm{COD}$, flow rate, temperature, and TSS were selected as the ANN model inputs [p], and effluent $\mathrm{pH}$, temperature, COD and TSS were taken as the outputs [t] (Fig. 1). The data were normalized in the range of $[0,1]$ according to the Eq.(1) as follows:

$\mathrm{X}_{\text {norm }}=0.1+\left(\mathrm{X}_{\text {real }}-\mathrm{X}_{\min }\right) /\left(\mathrm{X}_{\max }-\mathrm{X}_{\min }\right)^{*} 0.88$ 


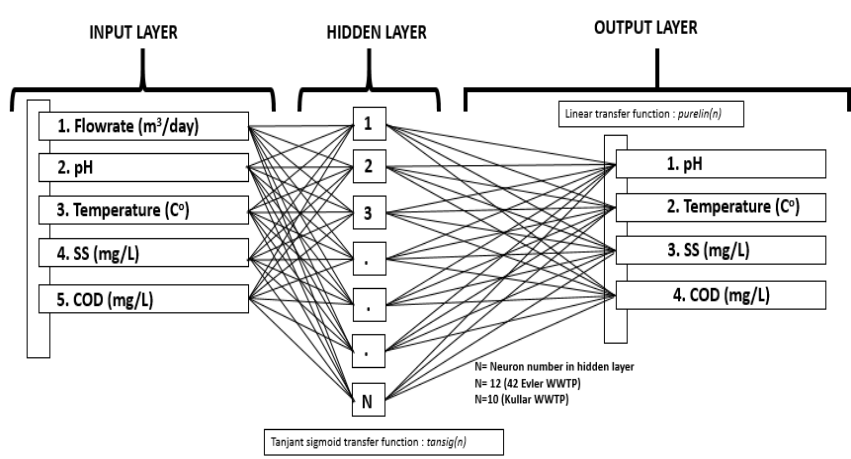

Figure 1. Topology of the neural network

The Neural Network Tool module of MATLAB (The MathWorks, Inc., USA, R16) software was used for modelling and prediction. The Bayesian Regularization training algorithm was chosen as training algorithm. The experimental data set was classified into training $(80 \%)$, validation $(10 \%)$, and testing $(10 \%)$ sets. In the current study, 400 data set were applied to develop ANN model for simulation of effluent $\mathrm{pH}$, temperature, COD and SS. The best ANN model was evaluated based on the mean square error (MSE) and correlation coefficient $\left(\mathrm{R}^{2}\right)$ metrics.

\section{Results and Discussion}

\subsection{Selection of optimum BP Training Algorithm}

In the artificial neural network modelling, it is important to examine which training algorithm is optimum depending on the number of data points [22]. Therefore, 13 training algorithms were conducted to choose the best correlated BP algorithm (Table 1 and 2). A three-layer network with a tangent sigmoid transfer function (tansig) at hidden layer and a linear transfer function (purelin) at output layer, was applied in all algorithms. Ten neurons were used at the hidden layer for all BP algorithms. The results indicated that the traingdx (Gradient descent w/momentum \& adaptive lr backpropagation), with a minimum MSE (0.0033) was chosen as the best fitted back propagation algorithm for 42 Evler WWTP. The regression values of training, validation and test using this function were found as 0.94, 0.96 and 0.95, respectively (Fig. 2). The benchmark comparisons revealed that the MSE value (0.0035) of trainbr function was also calculated as smaller compared to batch gradient descent (traingd) and with momentum (traingdm) training algorithms.
Table 1. Comparison of BP algorithms with ten neurons in the hidden layer (42 Evler WWTP)

\begin{tabular}{lllc}
\hline Function & $\mathbf{R}$ & $\mathbf{M S E}$ & Iteration Number \\
\hline trainbfg & 0.95443 & 0.0041602 & 39 \\
trainbr & 0.96613 & 0.0035403 & 207 \\
traincgb & 0.95774 & 0.0069559 & 30 \\
traincgf & 0.95774 & 0.0073913 & 59 \\
traincgp & 0.9569 & 0.0042638 & 31 \\
traingd & 0.87316 & 0.011423 & 1000 \\
traingdm & 0.90174 & 0.010609 & 1000 \\
traingda & 0.94341 & 0.007636 & 137 \\
traingdx & 0.95306 & 0.0033168 & 169 \\
trainlm & 0.95871 & 0.0038147 & 2 \\
trainoss & 0.95797 & 0.0048177 & 96 \\
trainrp & 0.95769 & 0.0052998 & 73 \\
trainscg & 0.95807 & 0.0038887 & 109 \\
\hline & & &
\end{tabular}

Table 2: Comparison of BP algorithms with ten neurons in the hidden layer (Kullar WWTP)

\begin{tabular}{lllc}
\hline Function & $\mathbf{R}$ & MSE & Iteration Number \\
\hline trainbfg & $\mathbf{0 . 9 6 3 8 4}$ & $\mathbf{0 . 0 0 0 9 2 5 0 2}$ & 58 \\
trainbr & 0.96734 & 0.0023474 & 564 \\
traincgb & 0.96054 & 0.0012083 & 38 \\
traincgf & 0.96361 & 0.0011186 & 89 \\
traincgp & 0.9572 & 0.0042441 & 19 \\
traingd & 0.82576 & 0.018563 & 1000 \\
traingdm & 0.95993 & 0.0011348 & 5000 \\
traingda & 0.94453 & 0.0021232 & 131 \\
traingdx & 0.81455 & 0.013858 & 66 \\
trainlm & 0.96645 & 0.0033744 & 8 \\
trainoss & 0.96027 & 0.0016085 & 40 \\
trainrp & 0.95949 & 0.0011929 & 81 \\
trainscg & 0.94576 & 0.0052459 & 12 \\
\hline
\end{tabular}




\section{Kocaeli (Turkey)}
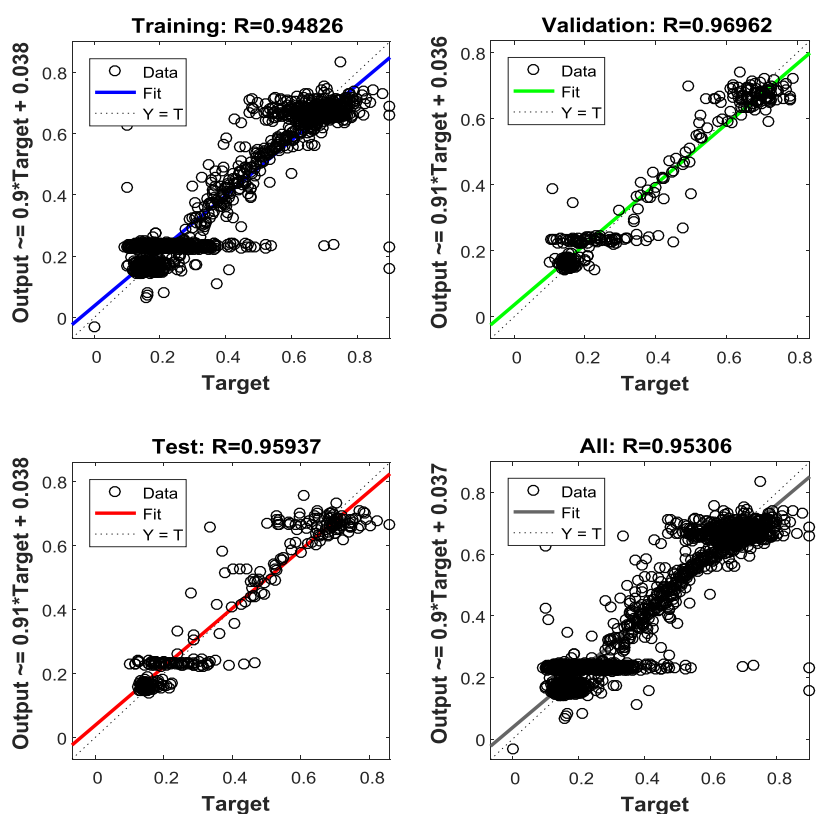

Figure 2. The prediction of ANN model by using traingdx function (42 Evler WWTP)

On the other hand, the comparison results for Kullar WWTP showed that the trainbfg (BFGS quasi-Newton backpropagation) was the best fitted algorithm with the lowest MSE (0.00092) and highest correlation coefficient $(\mathrm{R}=0.963)$ values. The regression values of training, validation and test of this function were found as 0.967 , 0.989 and 0.924 , respectively (Fig. 3).
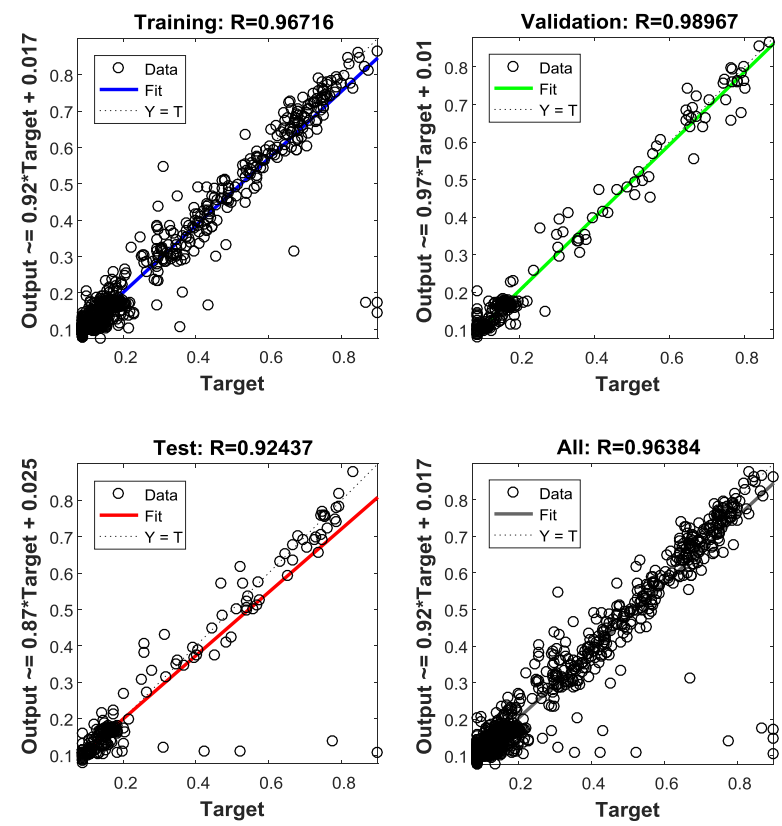

Figure 3. The prediction of ANN model by using trainbfg function (Kullar WWTP)

After selecting the best algorithm, the optimum activation function for a maximum regression value for training, validation and testing was investigated for both WWTPs and the results are shown in Table 3. According to the high regression coefficients, three-layer feed-forward ANN model with tansig at hidden layer and purelin at output layer were found optimum for the forecasts of effluent streams of both WWTPs.

Table 3: Effect of activation function on the ANN prediction

\begin{tabular}{|c|c|c|c|c|c|}
\hline \multirow[t]{2}{*}{ Run } & \multirow[t]{2}{*}{ Function } & \multirow[t]{2}{*}{$\begin{array}{l}\text { Neuron } \\
\text { number }\end{array}$} & \multicolumn{3}{|c|}{ Regression performance } \\
\hline & & & Training & Validation & Test \\
\hline \multicolumn{6}{|c|}{42 Evler WWTP } \\
\hline 1 & Tansig,Purelin & 10 & 0.948 & 0.969 & 0.953 \\
\hline 2 & Tansig, Logsig & 10 & 0.856 & 0.858 & 0.833 \\
\hline 3 & Tansig, Tansig & 10 & 0.950 & 0.962 & 0.942 \\
\hline 4 & Logsig, Purelin & 10 & 0.866 & 0.831 & 0.864 \\
\hline 5 & Logsig, Tansig & 10 & 0.940 & 0.926 & 0.930 \\
\hline 6 & Logsig, Logsig & 10 & 0.847 & 0.836 & 0.863 \\
\hline \multicolumn{6}{|c|}{ Kullar WWTP } \\
\hline 1 & Tansig,Purelin & 10 & 0.967 & 0.989 & 0.924 \\
\hline 2 & Tansig, Logsig & 10 & 0.952 & 0.982 & 0.954 \\
\hline 3 & Tansig, Tansig & 10 & 0.975 & 0.908 & 0.970 \\
\hline 4 & Logsig, Purelin & 10 & 0.958 & 0.953 & 0.980 \\
\hline 5 & Logsig, Tansig & 10 & 0.959 & 0.986 & 0.929 \\
\hline 6 & Logsig, Logsig & 10 & 0.355 & 0.333 & 0.364 \\
\hline
\end{tabular}

\subsection{Optimization of ANN Structure}

The key section of training the ANN model is to determine the most suitable number hidden layers and number of neurons per layer [12]. The larger networks can result in higher precision in the dataset, but leading an overfitting the model [23]-[24]. Thus, it is important to apply the least number of hidden layers and neurons which ensures high accuracy for both training and estimation. Anupam et al. [25] indicated that application of more hidden layer would lead the system more complex and increase the time. For this reason, the number of hidden layer was kept constant and the tests were conducted between MSE and neuron numbers in the hidden layer. At first, two neurons were applied in hidden layer and then the neuron numbers were increased and varying MSE values were calculated for the training set. 


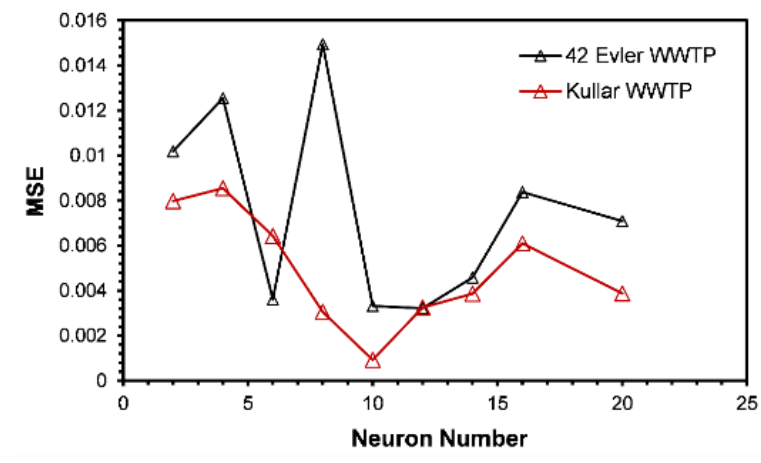

Figure 4. The dependence between MSE and number of neurons at hidden layer

Fig. 4 shows the dependence between the neuron number and MSE. For 42 Evler WWTP, the optimal neuron number was found to be 12 neurons (MSE 0.003) while that of for Kullar WWTP was found as 10 neurons (MSE 0.0009 ) for the estimation of output parameters. When the number of neurons decreased from 12 to 8, the MSE value increased significantly from 0.003 to 0.014 , for the 42 Evler WWTP. Similar phenomena was observed for Kullar WWTP. This increment could be attributed to the MSE performance index, and the properties of the input vectors [22]. It can be concluded that, ANNs are highly dependent on the number of neurons in their hidden layers. Yetilmezsoy et al. [22] indicated that the low neuron numbers could result in under-fitting, while higher neurons in hidden layer could lead to overfitting in which the fitting curves is composed of sharp oscillations. After selecting the optimum neuron numbers for WWTPs, the MSE graphics for the prediction of effluent streams of WWTPs were drawn as shown in Fig. 5.

(a)

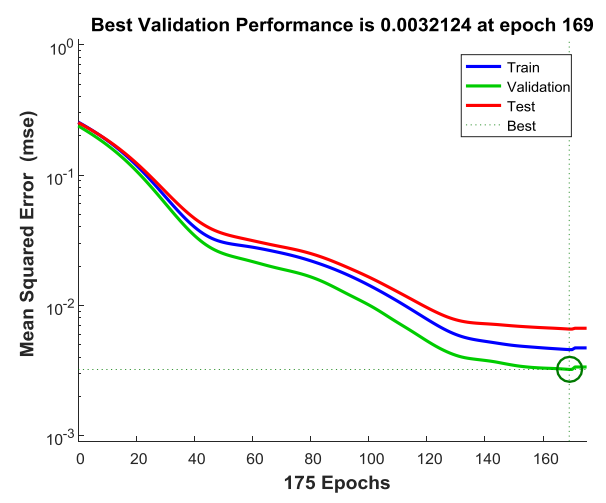

(b)

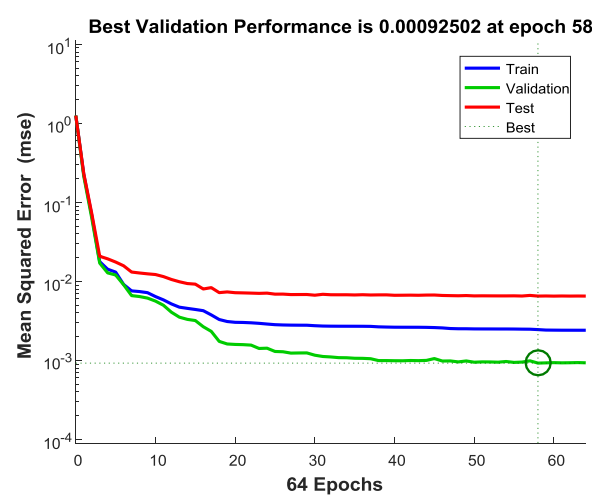

Figure 5. MSE graphics for the prediction of effluent streams of (a) 42 Evler WWTP (traingdx, N: 12) and (b) Kullar WWTP (trainbfg, N: 10)

\subsection{Prediction of Effluent Parameters of WWTPs}

The ANN modelling was performed between the observed output and the model response. The comparison between the corresponding data and the ANN outputs indicated that the predicted data were agreed with the experimental one (Fig. 6). The results indicated that the ANN method with smaller deviation showed a good simulation performance for estimating the water parameters namely $\mathrm{pH}$, Temperature, COD and SS. In Kullar WWTP, the data between April, 2013 and March, 2014 were missing due to the interruption in the plant. So, the data between these periods could not be evaluated during the ANN modelling.

Fig. 6(a) shows the comparison of effluent $\mathrm{pH}$ values of WWTPs. The pH of influent streams of 42 Evler WWTP were in the range of 7.0-8.0; while that of for Kullar WWTP were 6.3-7.5. The determination coefficient values $\left(\mathrm{R}^{2}=0.878\right.$ and 0.852$)$ for testing sets indicated that $12.2 \%$ and $14.8 \%$ of the total variations were not defined by the ANN method in the estimation of output $\mathrm{pH}$ values for 42 Evler and Kullar WWTPs, respectively.

Since the influent temperature has a significant effect on the municipal WWTPs combined with seasonal temperature changes. As shown in Fig 6(b), ANN model outputs presented a very small deviation of about 0.02 and 0.01 from the experimental data $\left(\mathrm{R}^{2}=0.9725\right.$ and 0.9864 ) for 42 Evler and Kullar WWTPs, respectively. The high correlation may be attributed to the fact that the temperature is not significantly affected by any treatment process; while it depends on the seasonal change.

The estimation of suspended solids (SS) is essential in controlling the quality of effluent stream since SS are classified as one of the major pollutants decreases the water quality. The input, observed and ANN testing output SS values were shown in Fig. 6(c). For both WWTPs, the observed output SS values were highly changed according to the unlimited concentrations -up to $2000 \mathrm{mg} / \mathrm{L}-$ at some 
(a)

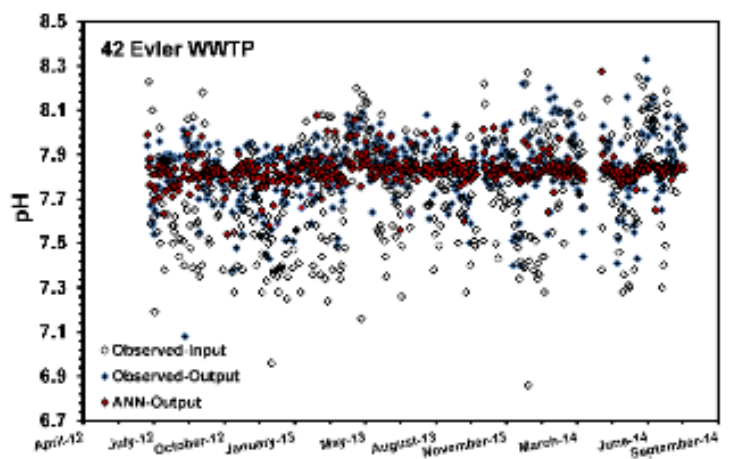

(b)

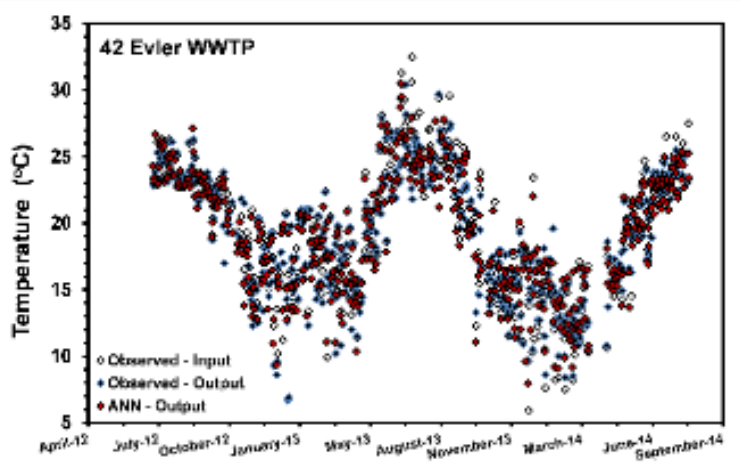

(c)

(d)

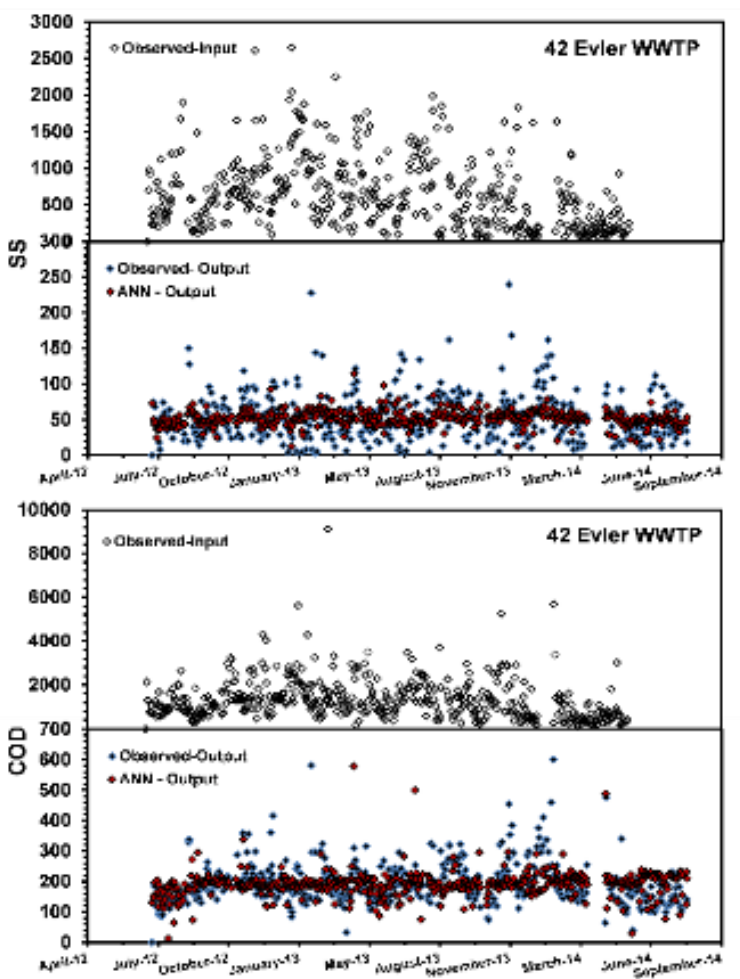

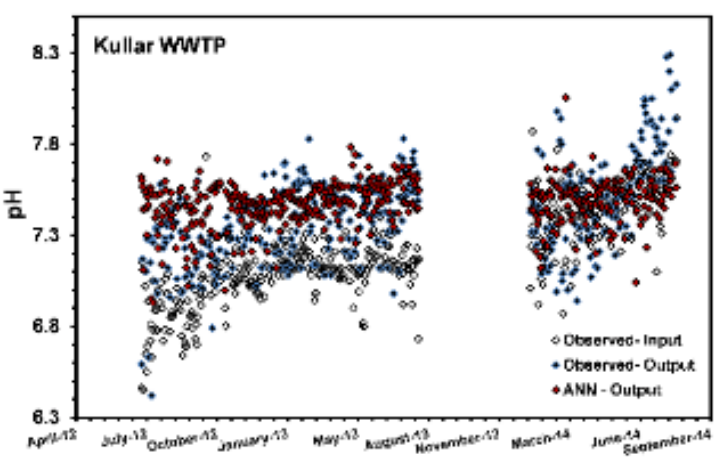
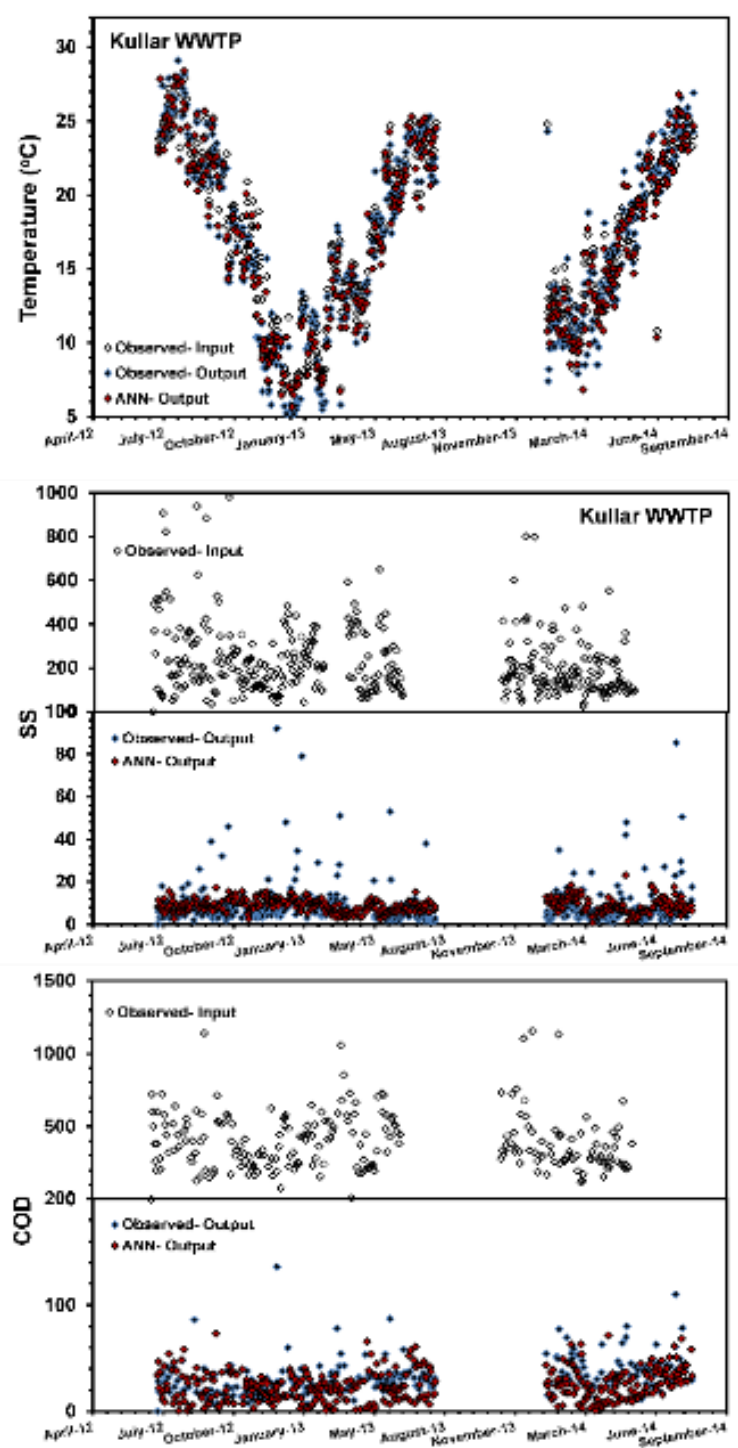

Figure 6. Comparison of visual agreements between the experimental and ANN simulations in estimation of output wastewater characteristics of (a) $\mathrm{pH}$, (b)Temperature $\left({ }^{\circ} \mathrm{C}\right)$, (c) SS and (d) COD 
months. The ANN model did not successfully predicted the effluent SS values especially above the boundary concentrations. Although ANN can deal with noisy and erroneous data, the process conditions in biological WWTPs change steadily and relative error in these might hinder the ANN model [26]. Therefore, after neglecting the exceeded concentrations, the correlation coefficients between ANN predicted outputs and measured values were calculated to be 0.7456 and 0.7248 , for 42 Evler and Kullar WWTPs, respectively.

Fig. 6(d) shows the COD values of observed and predicted output and also influent streams of WWTPs. The COD of influent streams of 42 Evler WWTP were in the range of 300-3000 mg/L; while that of for Kullar WWTP were 200-750 mg/L. The significant difference of COD values in the WWTPs could be due to the fact that the Kullar WWTP receives mainly domestic influent while 42 Evler WWTP receives a complex mixture of industrial and domestic wastewater. Therefore, the prediction of effluent of Kullar WWTP was found more accurate $\left(\mathrm{R}^{2}=\right.$ $0.924)$ when compared with 42 Evler WWTP $\left(R^{2}=0.873\right)$. In Turkey, the continuous prediction of COD is vitally important in each WWTP as it is essential to decrease the effluent quality below the standard for $90 \%$ of the time [Moral-2008]. However, the analysis of COD is difficult and time consuming. Therefore, in the current work, the applied ANN model with high accuracy is important for efficiently prediction of COD values in the effluent on a real time basis.

\section{Conclusion}

The estimation of effluent stream properties in the WWTPs is a critical issue due to the environmental effects of the water quality. However, the measurement of the parameters can be difficult and take days to obtain the analysis results which increased the cost. Herein, the applicability of artificial neural network technique in the estimation of effluent parameters has been demonstrated. The three-layer ANN model presented acceptable predictions on four effluent parameters with satisfactory determination coefficients. The optimum neuron values in the hidden layer were obtained as 12 and 10 with the related MSE numbers of 0.003 and 0.0009 , for the prediction of output parameters of 42 Evler and Kullar WWTPs, respectively. Statistical performance revealed that the suggested ANN model had a great predictive accuracy on simulation of $\mathrm{pH}$, temperature, SS and COD values of effluent streams.

\section{Acknowledgment}

This study was supported by Yalova University (project no. 2016/YL/068). Authors would like to offer special thanks to Kocaeli Metropolitan Municipality ISU for the data supply.

\section{References}

[1] Beltramo, T., Klocke, M., Hitzmann, B., "Prediction of the biogas production using GA and ACO input features selection method for ANN model", Inform. Process. Agri. 2019.

[2] Yetilmezsoy, K., Ozkaya, B., Cakmakci, M., "Artificial Intelligence-Based Prediction Models for Environmental Engineering", Neural Network World, 3/11, 193-218, 2011.

[3] Hanbay, D., Turkoglu, I., Demir, Y., "Prediction of wastewater treatment plant performance based on wavelet packet decomposition and neural networks", Expert Syst. Appl. 34 (2), 1038-1043, 2008.

[4] Gadekar, M. R., Mansoor Ahammed, M., "Modelling dye removal by adsorption onto water treatment residuals using combined response surface methodology-artificial neural network approach", J. Environ. Manage. 231, 241$248,2019$.

[5] Haykin, S. Neural networks and learning machines. Prentice Hall, 2008.

[6] Xiong, Q. and Jutan, A. "Grey-box modelling and control of chemical processes”, Chem. Eng. Sci. 57, 1027-1039, 2002.

[7] Canete, J. D., Saz-Orozco, P. D., Baratti, R., Mulas, M., Ruano, A., Garcia-Cerezo, A., "Soft-sensing estimation of plant effluent concentrations in a biological wastewater treatment plant using an optimal neural network", Expert Syst. Appl. 63, 8-19, 2016.

[8] Baklouti, I., Mansouri, M., Hamida, A. B., Nounou, H., Nounou, M., "Monitoring of wastewater treatment plants using improved univariate statistical technique", Process Saf. Environ. 116, 287-300, 2018.

[9] Harrou, F., Dairi, A., Sun, Y., Senouci, M., "Statistical monitoring of a wastewater treatment plant: A case study", J. Environ. Manage. 223, 807-814. 2018.

[10] Han, H.G., Zhang, L., Liu, H.-X., Qiao, J.-F., "Multiobjective design of fuzzy neural network controller for wastewater treatment process", Appl. Soft Comput. 67, 467-478, 2018.

[11] Vijayan, A., Mohan, G.S., "Prediction of Effluent Treatment Plant Performance in a Diary Industry Using Artificial Neural Network Technique", J. Civil Environ Eng 6, 6, 2016.

[12] Tümer, A.E., Edebali, S., "An Artificial Neural Network Model for Wastewater Treatment Plant of Konya", IJISAE, 3(4), 131-135, 2015.

[13] Wan, J., Huang, M., Ma, Y., Guo, W., Wang, Y., Zhang, H., Li, W., Sun, X., "Prediction of effluent quality of a paper mill wastewater treatment using an adaptive network-based fuzzy inference system", Appl. Soft Comput. 11, 3238-3246, 2011.

[14] Silva, I.N. and Flauzino, R.A., "An approach based on neural networks for estimation and generalization of crossflow filtration processes", Appl. Soft Comput. 8, 590-598, 2008.

[15] Holubar, P., Zani, L., Hager, M., Froschl, W., Radak, Z., Braun, R., "Advanced controlling of anaerobic digestion by means of hierarchical neural networks", Water Res. 36, 25822588, 2002.

[16] Çinar, Ö., "New tool for evaluation of performance of wastewater treatment plant: Artificial neural network", Process Biochem. 40, 2980-2984, 2005.

[17] Chen, J.C., Chang, N.B., Shieh, W.K., Assessing wastewater reclamation potential by neural network model", Eng. Appl. Artif. Intell. 16, 149-157, 2003. 
[18] Nasr, M. S., Moustafa, M.A.E., Seif, H.A.E., El Kobrosy, G., "Application of Artificial Neural Network (ANN) for the prediction of EL-AGAMY wastewater treatment plant performance-EGYPT", Alexandria Eng. J. 51, 37-43, 2012.

[19] Dias, A., Alves, M., Ferreira, E., Application of computational intelligence techniques for monitoring and prediction of biological wastewater treatment systems. In: In Proceedings of the Int. IWA Conf. on Automation in Water Quality Monitoring, 3:Gent, Belgium, 2007, Springer, pp. 18.

[20] Raduly, B., Gernaey, K.V., Capodaglio, A.G., Mikkelsen, P.S., Henze, M., "Artificial neural networks for rapid WWTP performance evaluation: Methodology and case study", Environ. Modell. Softw. 22, 1208-1216, 2007.

[21] Nadiri, A. A., Shokri, S., Tsai, F.T.C., Moghaddam, A. A. "Prediction of effluent quality parameters of a wastewater treatment plant using a supervised committee fuzzy logic model", J. Cleaner Prod. 180, 539-549, 2018.

[22] Yetilmezsoy, K., Turkdogan, F.I., Temizel, I., Gunay, A., "Development of Ann-Based Models to Predict Biogas and Methane Productions in Anaerobic Treatment of Molasses Wastewater", Int. J. Green Energy, 10:9, 885-907, 2013.

[23] Zaghloul, M.S., Hamza, R.A., Iorhemen, O.T., Tay, J.H., "Performance prediction of an aerobic granular SBR using modular multilayer artificial neural networks", Sci. Total Environ., 645, 449-459, 2018.

[24] Mjalli, F.S., Al-Asheh, S.A., Alfadala, H.E., "Use of artificial neural network black-box modeling for the prediction of wastewater treatment plants performance", J. Environ. Manage., 83, 329-338, 2007.

[25] Anupam, K., Dutta, S., Bhattacharjee, C., Datta, S., "Artificial neural network modelling for removal of chromium (VI) from wastewater using physisorption onto powdered activated carbon", Desal. Water Treat, 1-10, 2014.

[26] Moral, H., Aksoy, A., Gokcay, C.F.," Modeling of the activated sludge process by using artificial neural networks with automated architecture screening", Comput. Chem. Eng. 32 2471-2478, 2008. 